\title{
A loss of aggressive behaviour and its reinstatement by oestrogen in mice lacking the aromatase gene (Cyp19)
}

\author{
K Toda, T Saibara ${ }^{1}$, T Okada ${ }^{2}$, S Onishi ${ }^{1}$ and Y Shizuta \\ Department of Medical Chemistry, Kochi Medical School, Nankoku, Kochi 783-8505, Japan \\ ${ }^{1}$ Department of Internal Medicine, Kochi Medical School, Nankoku, Kochi 783-8505, Japan \\ ${ }^{2}$ Department of Anatomy and Cell Biology, Kochi Medical School, Nankoku, Kochi 783-8505, Japan \\ (Requests for offprints should be addressed to K Toda, Department of Medical Chemistry, Kochi Medical School, Nankoku, Kochi 783-8505, Japan; \\ Email: todak@kochi-ms.ac.jp)
}

\begin{abstract}
Aromatase P450 (CYP19) is an enzyme responsible for conversion of androgens to oestrogens. We generated CYP19 knockout (ArKO) mice by targeting disruption of the CYP19 gene and observed that the ArKO males exhibited a complete loss of aggressive behaviour against intruder mice when examined using a resident-intruder paradigm. The defect in the behaviour of ArKO males was reinstated when the mice received supplements of $17 \beta$ oestradiol soon after birth. Nevertheless, the cumulative duration of the behaviour displayed by the treated mice during the test period of $15 \mathrm{~min}$ was $19 \pm 10 \mathrm{~s}$, which was
\end{abstract}

much shorter than that displayed by wild-type males, $90 \pm 17 \mathrm{~s}$. When the supplementation was started at 7 days after birth, the defect was not restored. These findings illustrate an absolute requirement for oestrogen during the neonatal stage of a male's life for the development of the potential for aggression observed in adulthood. Furthermore, the present study demonstrates that ArKO males are a useful model in which to investigate the neural mechanisms by which aggressive behaviour is controlled. Journal of Endocrinology (2001) 168, 217-220

aggression (Cologer-Clifford et al. 1999). The importance of the oestrogens/oestrogen receptor (ER) signalling pathway in intermale aggression was also reported in a study on mice lacking one of the ERs, ER $\alpha(E R \alpha$ knockout mice, $\alpha E R K O)$, in which males rarely displayed aggression against olfactory bulbectomised wild-type males (Ogawa et al. 1997, 1998). Furthermore, higher activity of aromatase, an enzyme responsible for the conversion of androgen to oestrogen (Simpson et al. 1994), was detected in the amygdala of more aggressive mice during early ontogeny (Compaan et al. 1994). Participation of oestrogen in aggressive behaviour was also implicated in other vertebrates such as song birds, showing that inhibition of aromatase activity abolishes male aggressive behaviour during the non-breeding season (Soma et al. 2000).

Recently, we generated mice lacking aromatase (aromatase knockout (ArKO) mice) by targeted disruption of the aromatase P450 gene (Cyp19). Female ArKO mice are totally infertile and show features similar to those seen in ovariectomised mice, such as diminution in size of the uteri and decreased density of bones. In ArKO males, we observed a reduced reproductive ability and the development of hepatic steatosis, which is attributable, at least in part, to down-regulation of enzymatic activities involved in fatty-acid $\beta$-oxidation reactions in hepatocytes (Nemoto et al. 2000). 
In the present study, we investigated ethological aspects of oestrogen actions by analysing aggressive behaviour of ArKO mice using a resident-intruder test. In addition, we examined the effects of supplementation with $17 \beta$ oestradiol $\left(\mathrm{E}_{2}\right)$ on this behaviour. We found that the disruption of Cyp19 resulted in a complete loss of aggressive behaviour against an intruding male, and that the loss was effectively reversed by $\mathrm{E}_{2}$ supplementation when it was initiated within three days after birth at a relatively high dose.

\section{Materials and Methods}

\section{Animals}

All animals were maintained on a $12 \mathrm{~h}$ light/darkness cycle at $22{ }^{\circ} \mathrm{C}-25{ }^{\circ} \mathrm{C}$. A standard rodent chow (NMF; Oriental Yeast, Tokyo, Japan) and water were available ad libitum. For comparison of phenotypes, wild-type and knockout mice from the same litters were used. Animal care and experiments were carried out in accordance with institutional animal regulations. We took special care to avoid any animals being injured during the intermale aggression experiments.

\section{$E_{2}$ supplementation}

$\mathrm{E}_{2}$ was dissolved in sesame oil. The schedule for $\mathrm{E}_{2}$ supplementation was determined empirically as follows. A group of mice received subcutaneous injections initiated on the day of birth with the following amounts of $E_{2}$ in a volume of $25 \mu \mathrm{l}: 7 \cdot 5 \mathrm{ng}$ ( $n=10$ ArKO males), $0.75 \mu \mathrm{g}$ $(n=10), 1.5 \mu \mathrm{g}(n=7), 7 \cdot 5 \mu \mathrm{g}(n=9)$, and $15 \mu \mathrm{g}(n=7)$. The injections were carried out every fourth day until day 21 after birth. Twenty-five microlitres of sesame oil were injected into mice as controls $(n=7)$. Then, mice received weekly injections of $0.75 \mu \mathrm{g} \mathrm{E}_{2}$ (experimental) or vehicle alone (control) until the end of the experiments. Mice that received $7.5 \mathrm{ng} \mathrm{E}_{2}$ were also given weekly injections of $7 \cdot 5 \mathrm{ng} \mathrm{E}_{2}$ after day 21 following birth. In another group of mice, the injections of $7 \cdot 5 \mu \mathrm{g} \mathrm{E} \mathrm{E}_{2}$ were initiated on day 3 $(n=13)$, day $5(n=14)$, day $7(n=10)$ or day $15(n=12)$ after birth. The injections were repeated every fourth day until day 21 after birth. Thereafter, they received weekly injections of $0.75 \mu \mathrm{g} \mathrm{E}$ until the end of the experiments. The third group of males $(n=10)$ was supplemented with $7 \cdot 5 \mu \mathrm{g} \mathrm{E}_{2}$ on the day of birth and on day 4 after birth without any other $\mathrm{E}_{2}$ injections. Analyses were performed on animals at $12-16$ weeks of age.

\section{Analysis of intermale aggression}

The aggressive behavioural test was performed in a standard polycarbonate mouse cage $(23 \times 16 \times 13 \mathrm{~cm})$ in a dimly-lit room between 1800 and $2000 \mathrm{~h}$. A resident-intruder test was employed to evaluate the intermale aggression (Ogawa et al. 1998). Wild-type and ArKO males kept individually for two weeks prior to the test were used as residents. ArKO or wild-type mice, housed in a group, were used as intruders. Since ArKO males were not aggressive towards wild-type males and did not themselves initiate any fights, they were used as intruders when examining the effects of $E_{2}$ supplementation on ArKO males. An intruder was transferred to the home cage of a resident and the behaviour was tape-recorded for $15 \mathrm{~min}$. The cumulative duration of aggressive behaviour such as wrestling, biting attacks, lateral threats, and tail rattling was determined. The effects of $E_{2}$ on intermale aggression of ArKO mice were evaluated by counting the number of mice showing aggressive behaviour towards intruders during the test.

\section{Statistical analysis}

Data were analysed by the Kruskal-Wallis test for multiple comparisons. The $P$ value obtained was $<0.0001$ (see Figs 1 and 2).

\section{Results and Discussion}

Wild-type male mice showed aggressive behaviour against an intruder mouse under the experimental conditions as shown in Fig. 1. The cumulative durations of the attacks were about $2.5 \mathrm{~min}$ and $1.5 \mathrm{~min}$ against wild-type and ArKO intruder mice respectively. In contrast, ArKO males did not show such behaviour.

When neonatal ArKO males were given $\mathrm{E}_{2}$ at a concentration of $7 \cdot 5 \mu \mathrm{g} /$ mouse or more, the mice showed aggression against an intruder as they grew to $12-16$ weeks of age. Although the treatment apparently restored male aggressive behaviour, the cumulative duration of the behaviour displayed by the treated mice was $19 \pm 10 \mathrm{~s}$ $(n=9)$. This duration was significantly shorter than that of the wild-type mice $(90 \pm 17 \mathrm{~s})$, indicating that the conditons for $\mathrm{E}_{2}$ supplementation employed in the present study were suboptimal. Indeed, the highest levels of aromatase activity in the brain are detected during the prenatal stage in rodents, approximately two to three days before birth (Lephart 1996). Thus, we assumed that a more profound effect of $\mathrm{E}_{2}$ on aggressive behaviour would be expected if we administered $\mathrm{E}_{2}$ during the prenatal stage.

Supplementation with reduced amounts of $E_{2}$ exerted marginal effects on aggressive behaviour (Fig. 2A). The efficiency of restoration of aggressive behaviour by $\mathrm{E}_{2}$ depended on the time when the supplementation was initiated after birth (Fig. 2B). When it was initiated at 7 days after birth, only three of ten mice showed aggression and when initiated at 15 days after birth, no mice exhibited aggression. It has previously been reported that 


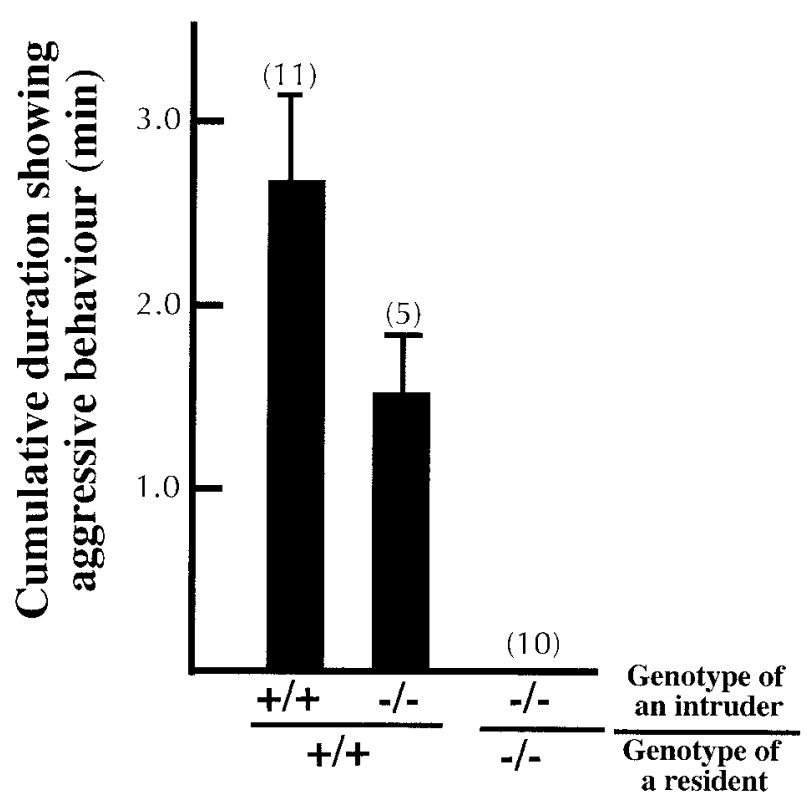

Figure 1 Loss of aggression in ArKO mice. Cumulative duration of aggressive behaviour was scored by means of a resident-intruder test. Wild-type mice $(+/+)$ were examined with a group-housed wild-type $(+/+)$ or ArKO $(-/-)$ mouse. ArKO mice $(-/-)$ were examined only with an ArKO $(-/-)$ mouse. Numerals in parentheses are the number of mice examined. $P<0 \cdot 0001$ (by the Kruskal-Wallis test).

male mice castrated on the day of birth are less aggressive than males castrated 10 days later when both are given androgens as adults and tested for aggression (Edwards 1969, Peters et al. 1972, Monteica-Heino et al. 1993). These findings indicate that endogenous testicular androgens have their greatest effect on the organisation of mechanisms for aggressive behaviour during the first few days after birth (Monteica-Heino et al. 1993). The findings of the present study support the importance of the first few days after birth for hormonal stimuli that trigger the process for development of the potential for adult aggressive behaviour. Nevertheless, the present studies demonstrate that the functional molecule needed to regulate the process appears to be oestrogen rather than testicular androgen.

Mice supplemented with $\mathrm{E}_{2}$ only twice during the neonatal stage, namely on the day of birth and on day 4 after birth, did not show aggression. These results indicate that $\mathrm{E}_{2}$ might be required continuously from birth. Alternatively, there might be other critical periods, in addition to the neonatal stage, at which $\mathrm{E}_{2}$ plays an essential role in the development of the potential for adult intermale aggression. The requirement for steroid hormones during a stage of life other than the perinatal period was suggested by the studies of castration-replacement experiments, where the perinatal surge in plasma testosterone was interpreted as providing an initial stimulus for triggering
A

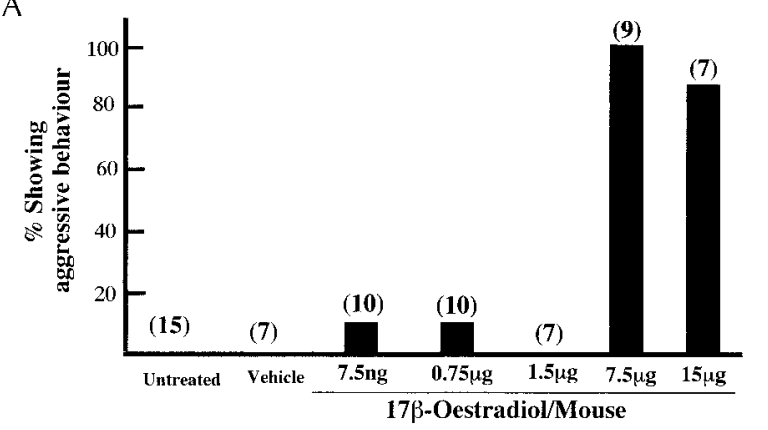

B

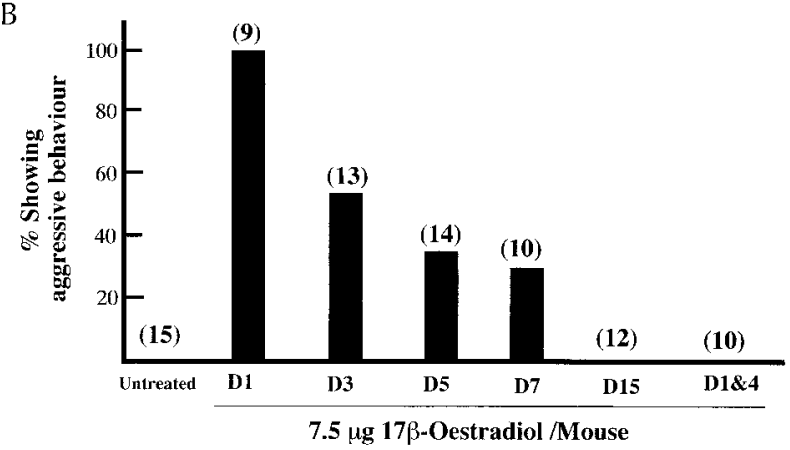

Figure 2 Reinstatement of the aggressive behaviour of ArKO mice with $E_{2}$. (A) Dose-dependency of the reinstatement. Mice were supplemented on the day of birth with various amounts of $E_{2}$ as indicated. The supplementation was repeated every fourth day until day 21 , and was followed by weekly injections of $0 \cdot 75 \mu \mathrm{g}$ $E_{2} /$ mouse until the experiment ended. 'Vehicle' indicates a group of ArKO males injected with $25 \mu \mathrm{l}$ sesame oil in a similar fashion. 'Untreated' indicates a group of ArKO males that did not receive any injection. (B) ArKO mice were supplemented with 7.5 $\mu \mathrm{g} \mathrm{E}_{2}$ per mouse on day 1, 3, 5, 7 or 15 after birth (as indicated by D1, D3, D5, D7 or D15). Then the supplementation was repeated as described above. The mice in the group shown by D1\&4 were given $E_{2}$ only on days 1 and 4 after birth. The untreated mice and mice treated from day 1 are the same as those used in the experiments for examining the dose-dependency. The numerals in parentheses over each bar indicate the numbers of mice examined. The reinstatement rate was calculated by dividing the number of mice showing aggressive behaviour against an intruder by the number of mice examined and was expressed as a percentage. $P<0 \cdot 0001$ (by the Kruskal-Wallis test).

the postnatal process essential for adult aggressive behaviour, rather than making a unique contribution (Monteica-Heino et al. 1993.). A loss of aggression was also reported in $\alpha$ ERKO (Ogawa et al. 1997, 1998), but not in $\beta E R K O$ mice (Krege et al. 1998). This suggests that oestrogens regulate male aggressive behaviour through actions of $E R \alpha$ in the brain.

Mice generated by disruption of genes encoding monoamine oxidase A (Cases et al. 1995), adenosine receptor type $\mathrm{A}_{2 \mathrm{a}}$ (Ledent et al. 1997), 5hydroxytryptamine receptor 1B (Ramboz et al. 1996), neuronal nitric-oxide synthase (Nelson et al. 1995) or 
$\alpha$-calcium-calmodulin-kinase II (Chen et al. 1994) exhibited more aggressive behaviour than their wild-type littermates. Thus, expression of one or several of these genes might be regulated either directly or indirectly in an oestrogen-dependent manner in the brain. Chemosensory perception unquestionably plays an important role in intermale aggression in mice (Bean 1982, Clancy et al. 1984) and bilateral removal of the olfactory bulbs eliminates intermale fighting (Edwards et al. 1993). Thus, it is also possible that not only the central nervous system, but also the olfactory system, including the sensors for pheromones, might be restored by $\mathrm{E}_{2}$ supplementation. Whatever the sites of actions of $\mathrm{E}_{2}$, the experimental conditions established in the present study highlight a method for the search and characterisation of genes playing important roles in aggressive behaviour.

\section{Acknowledgments}

This work was supported in part by research grants from ONO Medical Research Foundation and from TOYOTA High-Tech Research Grant Program (K T).

\section{References}

Albert DJ, Walsh ML, Gorzalka BB, Mendelson S \& Zalys C $1986 a$ Intermale social aggression: suppression by medial preoptic area lesions. Physiology and Behavior 38 169-173.

Albert DJ, Walsh ML, Gorzalka BB, Siemens Y \& Louie H 1986 b Testosterone removal in rats results in a decrease in social aggression and a loss of social dominance. Physiology and Behavior 36 401-407.

Albert DJ, Dyson EM \& Walsh ML 1987a Intermale social aggression: reinstatement in castrated rats by implants of testosterone propionate in the medial hypothalamus. Physiology and Behavior 39 555-560.

Albert DJ, Dyson EM, Walsh ML \& Gorzalka BB $1987 b$ Intermale social aggression in rats: suppression by medial hypothalamic lesions independently of enhanced defensiveness or decreased testicular testosterone. Physiology and Behavior 39 693-698.

Barfield RJ, Busch DE \& Wallen K 1972 Gonadal influence on agonistic behavior in the male domestic rat. Hormones and Behavior 3 247-259.

Bean NJ 1982 Modulation of agonistic behavior by the dual olfactory system in male mice. Physiology and Behavior 29 433-437.

Brain PF \& Haug M 1992 Hormonal and neurochemical correlates of various forms of animal 'aggression'. Psychoneuroendocrinology 17 $537-551$.

Cases O, Seif I, Grimsby J, Gaspar P, Chen K, Pournin S, Muller U, Aguet M, Babinet C, Shih JC \& De Maeyer ED 1995 Aggressive behavior and altered amounts of brain serotonin and norepinephrine in mice lacking MAOA. Science 268 1763-1766.

Chen C, Rainnie DG, Greene RW \& Tonegawa S 1994 Abnormal fear response and aggressive behavior in mutant mice deficient for a-calcium-calmodulin kinase II. Science 266 291-294.
Clancy AN, Coquelin A, Macrides F, Gorski RA \& Nobe EP 1984 Sexual behavior and aggression in male mice: involvement of the vomeronasal system. Journal of Neuroscience 4 2222-2229.

Cologer-Clifford A, Simon NG, Richter ML, Smoluk SA \& Lu S 1999 Androgens and estrogens modulate 5-HT1A and 5-HT1B agonist effects on aggression. Physiology and Behavior 65 823-828.

Compaan JC, Hutchinson JB, Wozniak A, de Ruiter AJ \& Koolhaas JM 1994 Brain aromatase activity and plasma testosterone levels are elevated in aggressive male mice during early ontogeny. Developmental Brain Research 82 185-192.

Edwards DA 1969 Early androgen stimulation and aggressive behavior in male and female mice. Physiology and Behavior 4 333-338.

Edwards DA, Nahai FR \& Wright P 1993 Pathways linking the olfactory bulbs with the medial preoptic anterior hypothalamus are important for intermale aggression in mice. Physiology and Behavior 53 611-615.

Krege JH, Hodgin JB, Couse JF, Enmark E, Warner M, Mahler JF, Sar M, Korach KS, Gustafsson J-Å \& Smithies O 1998 Generation and reproductive phenotypes of mice lacking estrogen receptor $\beta$. PNAS 95 15677-15682.

Ledent C, Vaugeois J, Schiffmann SN, Pedrazzini T, Yacoubi ME, Vanderheaghen J, Costentin J, Heath JK, Vassart G \& Parmentier M 1997 Aggressiveness, hypoalgesia and high blood pressure in mice lacking the adenosine A2a receptor. Nature 388 674-678.

Lephart ED 1996 A review of brain aromatase cytochrome P450. Brain Research Reviews 22 1-26.

Moteica-Heino I, Edwards DA \& Roffi J 1993 Intermale aggression in mice: does hour of castration after birth influence adult behavior? Physiology and Behavior 53 1017-1019.

Moyer K 1976 The Psycobiology of Aggression. New York: Harper \& Row.

Nelson RJ, Demas GE, Huang PL, Fishman MC, Dawson VL, Dawson TM \& Snyder SH 1995 Behavioural abnormalities in male mice lacking neuronal nitric oxide synthase. Nature 378 383-386.

Nemoto Y, Toda K, Ono M, F-Adachi K, Saibara T, Onishi S, Enzan H, Okada T \& Shizuta Y 2000 Altered expression of fatty acid-metabolizing enzymes in aromatase-deficient mice. Journal of Clinical Investigation 105 1819-1825.

Ogawa S, Lubahn DB, Korach KS \& Phaff DW 1997 Behavioral effects of estrogen receptor gene disruption in male mice. PNAS 94 1476-1481.

Ogawa S, Washburn TF, Taylor J, Lubahn DB, Korach KS \& Phaff DW 1998 Modification of testosterone-dependent behaviors by estrogen receptor- $\alpha$ gene disruption in male mice. Endocrinology 139 5058-5069.

Peters PJ, Bronson FH \& Whitsett JM 1972 Neonatal castration and intermale aggression in mice. Physiology and Behavior 8 265-268.

Ramboz S, Saudou F, Amara DA, Belzung C, Segu L, Misslin R, Buhot M \& Hen R 1996 5-HT1B receptor knock out behavioural consequences. Behavioural Brain Research 73 305-312.

Simpson ER, Mahendroo MS, Means GD, Kilgore MW, Hinshelwood MM, Graham-Lorence S, Amarneh B, Ito Y, Fisher CR, Michael D, Mendelson CR \& Bulun SE 1994 Aromatase cytochrome P450, the enzyme responsible for estrogen biosynthesis. Endocrine Reviews 15 342-355.

Soma KK, Tramontin AD \& Wingfield JC 2000 Oestrogen regulates male aggression in the non-breeding season. The Royal Society Proceedings: Biological Sciences 267 1089-1096.

Received 13 July 2000

Accepted 27 September 2000 